with unpleasant recall in this group is considerably smaller than the proportion found in the previous series; but again the size of population (118 previously in the atropine group) must affect the distribution, and therefore the percentage obtained from the current series is, as in the narcotic group, less reliable than the previous series.

TABLE I.-Results of Present Series of 82 Patients Receiving a Narcotic, Diazepam, or Atropine alone, before Caesarean Section, Correlated with the Incidence of Awareness, Pain, and Types of Dream in each Group

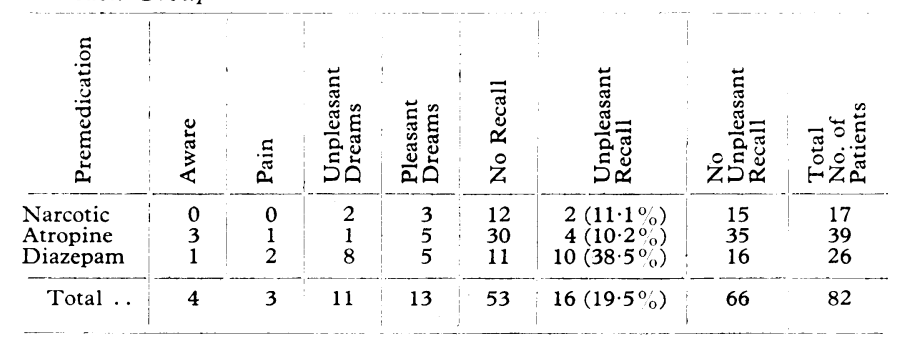

The most significant trend is seen in the group premedicated with diazepam. Of the total of 26 , one patient had recall of awareness with pain; one with pain recall alone; but eight with recall of unpleasant dreams. Thus the percentage of unpleasant recall in this group is $38.5 \%$ (10 patients). Though the figures for actual awareness and for pain recall are not significantly different from the atropine group, the degree of unpleasant dreaming is considerably increased. The difference between the groups receiving diazepam and atropine (Table I) shows that the likelihood of unpleasant recall is statistically significantly increased $\left(X^{3}=5 \cdot 7, P<0 \cdot 025\right)$ by the administration of diazepam.

\section{Discussion}

As we suggested in the conclusion to our previous paper (Wilson and Turner, 1969) we have investigated the effect of using one of the benzodiazepine group of tranquillizers (diazepam) as a premedicant in elective section in reducing the degree of unpleasant recall. Though this drug apparently, however, does not affect the degree of recall of facts from the period of anaesthesia or of recall of pain, it may be assumed that it considerably increases the likelihood of patients having unpleasant dreams during their anaesthetic. If the group of patients who received diazepam in this series is compared with the group who received atropine only in our previous series (Table II) a similar tendency to have unpleasant recall is demon-

TABLE II.-Incidence of Unpleasant Recall in Patients Receiving Atropine Premedication (previous series, Wilson and Turner, 1969) and in those Receiving Diazepam (present series)

\begin{tabular}{|c|c|c|c|}
\hline Premedication & $\begin{array}{l}\text { Unpleasant } \\
\text { Recall }\end{array}$ & $\begin{array}{l}\text { No Unpleasant } \\
\text { Recall }\end{array}$ & Total \\
\hline $\begin{array}{l}\text { Atropine (last series) } \\
\text { Diazepam .. }\end{array}$ & $\begin{array}{l}25(21 \%) \\
10(38.5 \%)\end{array}$ & $\begin{array}{l}93 \\
16\end{array}$ & $\begin{array}{r}118 \\
26\end{array}$ \\
\hline Total $\quad$. & $35\left(24 \cdot 3_{0}^{\circ}\right)$ & 109 & 144 \\
\hline
\end{tabular}

Although there is a marked rise in the percentage of unpleasant recall in the diazepam group $\left(38.5^{\circ}\right)$ from the atropine group in the previous series $\left(21^{\circ}\right)$, the

strated in the diazepam group. Apart from the use of diazepam as the premedicant in this series, there were no other differences in the anaesthetic procedure between the two series. Consequently diazepam is probably to blame for the increase in unpleasant recall, and therefore is not a suitable premedicant for this type of anaesthesia. As a consequence of these results we have felt obliged to end the current investigation before we had intended. It must be made clear, however, that this trial was of a combination of oral and intramuscular diazepam premedication in anaesthesia for caesarean section. This, therefore, in no way casts doubts on the good results obtained by the use of this drug to produce amnesia when given intravenously (Kurland, 1968), or on its success as a premedicant for other general anaesthetic techniques (Gordon and Turner, 1969 ) or as an induction agent (Kyles, 1968). Of the many suggestions received after our previous paper, that of the use of intravenous hyoscine would appear to hold out greatest promise, and requires further investigation.

\section{REFERENCES}

Gordon, N. H., and Turner, D. J. (1969). British fournal of Anaesthesia, 41, 136

Kurland, P. (1968). British Dental fournal, 125, 302.

Kyles, J. R. (1968). Presidential Address to the Scottish Society of Anaesthetists, April.

Wilson, J., and Turner, D. J. (1969). British Medical fournal, 1, 280.

\title{
Pigmentation in Megaloblastic Anaemia Associated with Pregnancy and Lactation
}

\author{
N. BAUMSLAG, * M.B. ; J. METZ, $†$ M.D., M.C.PATH.
}

Summary : Generalized skin pigmentation in five $S$ African women with megaloblastic anaemia in the postnatal period was associated with low serum folate levels, as distinct from vitamin $B_{12}$ deficiency. It is suggested that the occurrence of pigmentation in both folate and vitamin $B_{12}$ deficiency may reflect a common abnormality of metabolism.

* South African Institute for Medical Research, Johannesburg. Present Address: Department of Environmental Health, University of Cincinnati Medical School, Cincinnati, Ohio 45219.

\section{Introduction}

Brownish pigmentation of the skin, which may be diffuse or blotchy, has long been recognized in pernicious anaemia (Wintrobe, 1967). Baker et al. (1963) suggested that this pigmentation may be specific for vitamin- $\mathrm{B}_{12}$ deficiency. These authors described deep brown or brownish black pigmentation of the skin, most pronounced in the hands and feet. In some cases there was patchy pigmentation over the palms and soles, and pigmentation also occurred in the buccal mucous membrane with spotty pigmentation of the tongue. The pigmentation 
was due to excessive deposition of melanin. All these patients had low serum vitamin- $B_{12}$ levels, while in those in whom the serum folate was measured the values varied. The pigmentation disappeared on administration of vitamin $\mathrm{B}_{12}$. Baker et al. (1963) concluded that the pigmentation was related to vitamin $B_{12}$ rather than folate deficiency, and that the pigmentation was so typical as to be practically diagnostic of vitamin- $B_{12}$ deficiency.

Increased pigmentation has, however, been observed in megaloblastic anaemia associated with folate rather than vitamin-B $\mathrm{B}_{12}$ deficiency. Gough et al. (1963) noted that seven patients with megaloblastic anaemia due to dietary deficiency of folic acid all had greyish brown pigmentation of the skin, particularly of the exposed parts. All seven patients had low serum folate levels, while in only one was the serum vitamin $\mathrm{B}_{12}$ subnormal. To our knowledge increased pigmentation has not been previously recorded in folate deficiency associated with pregnancy and lactation, and it is the purpose of this communication to show that pigmentation identical to that described in vitamin- $B_{12}$ deficiency occurs in this form of megaloblastic anaemia.

\section{Present Findings}

Megaloblastic anaemia associated with pregnancy and lactation is the commonest form of megaloblastic anaemia seen in the adult African (Cassel and Metz, 1958). This syndrome is an example of pure folate deficiency, for the serum folate levels are subnormal (Stevens et al., 1962), serum vitamin-B $B_{12}$

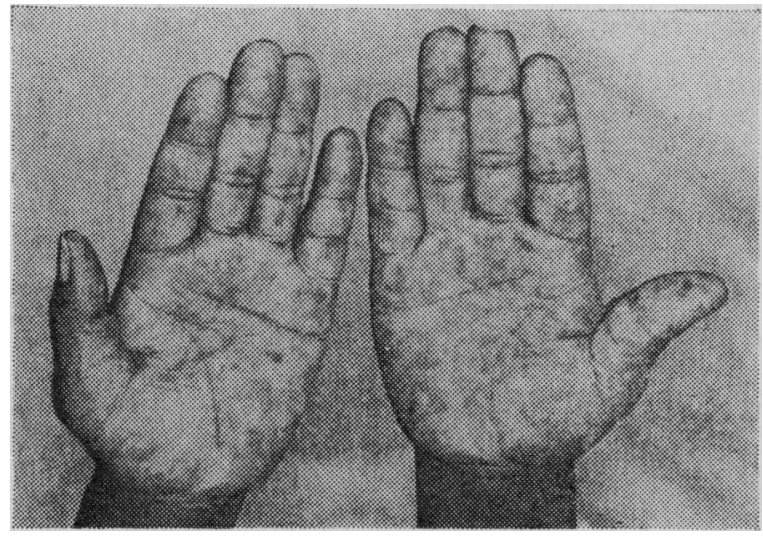

FIG. 1.-Spotty pigmentation of the palms.

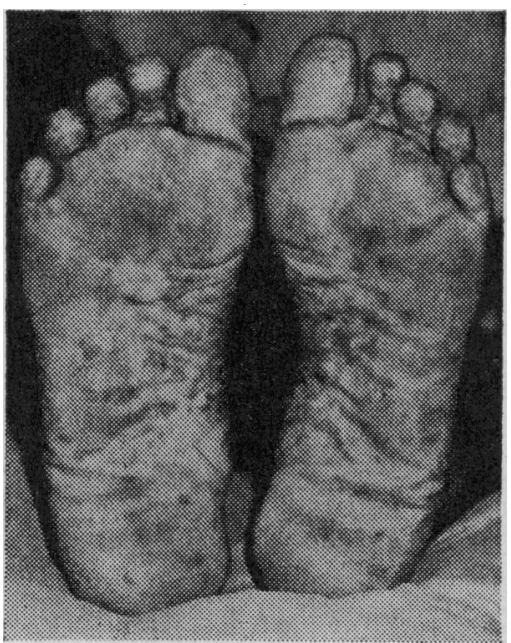

FIG. 2.-Spotty pigmentation of the soles.

concentration is usually normal (Metz et al., 1962), and haematological response follows the administration of physiological doses of folic acid, but not of vitamin $\mathrm{B}_{12}$ (Stevens and Metz, 1964). In five such patients who were lactating, having delivered infants within the three months before admission to hospital with megaloblastic anaemia, a typical form of pigmentation was noted. There was spotty pigmentation of the palms and soles in all (Figs. 1 and 2), and in one patient pigmentation of the tongue (Fig. 3) was present. This pigmentation was a chocolate brown colour and occasional spots were almost black. The palms and soles were extremely pale, thus rendering the pigmentation very prominent. Biopsy of a pigmented spot carried out in one patient showed an increase in the number of melanophores. Palmar and interphalangeal creases were deeply pigmented.

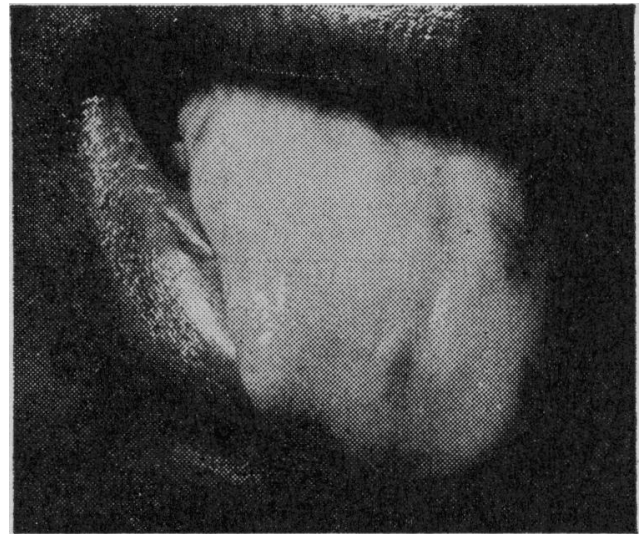

FIG. 3.-Spotty pigmentation of the tongue.

All these patients had negative serology for syphilis, and there was no clinical evidence of pellagra. In Cases 1-3 serum folate levels were extremely low, while the serum vitamin- $B_{12}$ concentrations were normal (see Table). In Case 4 serum folate was not estimated, but serum vitamin $B_{12}$ was normal

Serum Vitamin-B $B_{12}$ and Folate Levels in Four Patients with Lactational Megaloblastic Anaemia and Spotty Pigmentation of the Palms and Soles

\begin{tabular}{c|c|c}
$\begin{array}{c}\text { Case } \\
\text { No. }\end{array}$ & $\begin{array}{c}\text { Serum Vitamin } B_{12} \\
(\mu \mu \mathrm{g} . / \mathrm{ml} .)\end{array}$ & $\begin{array}{c}\text { Serum Folate } \\
(\mathrm{m} \mu \mathrm{g} . / \mathrm{ml} .)\end{array}$ \\
\hline 1 & 510 & $1 \cdot 2$ \\
2 & 680 & 0.8 \\
3 & 305 & $0 \cdot 6$ \\
4 & 220 & $*$
\end{tabular}

* Serum folate was not estimated; however, after administration of a 5-g. histidine load, $219 \mathrm{mg}$. of formiminoglutamic acid was excreted in the urine (normal less than $6 \mathrm{mg}$.).

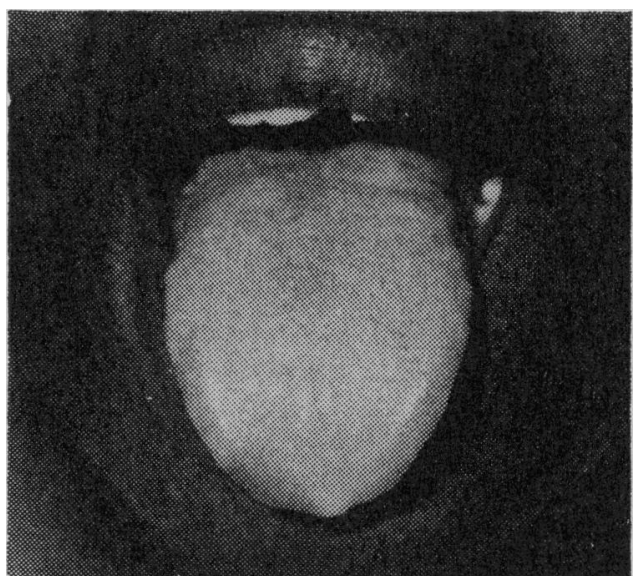

Frg. 4.-Pigmentation has disappeared following treatment with folic acid.

and there was marked excessive formiminoglutamicaciduria following histidine loading. Case 5 was admitted to hospital in extremis and received treatment previous to blood being drawn for serum vitamin- $\mathrm{B}_{12}$ and folate estimation. The pigmentation disappeared after therapy with folic acid. This is illustrated in the tongue (Fig. 4). 
A total of 600 control subjects were examined for this type of pigmentation. The controls consisted of 300 African women attending the antenatal and postnatal clinics at Baragwanath Hospital, and 300 African nurses at the hospital. The age distribution of the control groups was similar to that of the patients. In no subject was any evidence of this type of pigmentation noted. Thus there seems little doubt that the pigmentation described is related to folate deficiency. It is not a feature of race or pregnancy in the African, as demonstrated in the control groups. It is not due to anaemia per se, for it was not noted in other forms of anaemia.

The pigmentation in these patients with folate deficiency is similar to that described by Baker et al. (1963) in vitamin-B $B_{12}$ deficiency, and cannot therefore be regarded as specific for either vitamin. The cause of this pigmentation is not known. As it occurs in both vitamin- $\mathrm{B}_{12}$ and folate deficiency the abnormality may lie in a pathway common to both vitamins.
We wish to thank the Director, South African Institute for Medical Research, for facilities to carry out this study.

REFERENCES

Baker, S. J., Ignatius, M., Johnson, S., and Vaish, S. K. (1963). British Medical fournal, 1, 1713.

Cassel, R., and Metz, J. (1958). Medical Proceedings, 4, 278.

Gough, K. R., Read, A. E., McCarthy, C. F., and Waters, A. H. (1963). Quarterly fournal of Medicine, 32, 243.

Metz, J., Brandt, V., and Stevens, K. (1962). British Medical fournal, 1,24 .

Stevens, K., and Metz, J. (1964). Transactions of the Royal Society of Tropical Medicine and Hygiene, 58, 510.

Stevens, K., Metz, J., Brandt, V., and Van Broekhuizen, L. (1962). East African Medical fournal, 39, 222.

Wintrobe, M. M. (1967). Clinical Hematology, 6th ed., p. 508. Philadelphia, Lea and Febinger.

\section{Medical Memoranda}

\section{Nephrotic Syndrome Cured by Removal of Gastric Carcinoma}

British Medical fournal, 1969, 2, 739-740

The association of malignant disease with the nephrotic syndrome has been recorded (Black, 1967), though the exact causal relationship has usually been attributed to amyloidosis (Kimball, 1961) or renal vein thrombosis (Harrison, Milne, and Steiner, 1956), or both (Barclay, Cameron, and Loughridge, 1960). Lee, Yamauchi, and Hopper (1966), however, described a group of 11 cases in which malignancy and the nephrotic syndrome were associated, with no evidence of renal vein thrombosis and with renal histology in every instance free of amyloidosis. They postulated a different form of interrelated pathology, perhaps due to altered immune mechanisms. In no case in the series were both conditions reversible.

This paper describes a case in which the nephrotic syndrome was associated with gastric carcinoma, and in which subtotal gastrectomy was successful in relieving both conditions for at least 10 years.

\section{CAse History}

In November 1953 the patient, a man aged 60, had diarrhoea with soft offensive mucoid motions, colicky abdominal pains, and flatulence. Four months later he began to develop gross oedema, first in the scrotum, then spreading to the legs and trunk. He reported loss of weight, nausea, and vomiting but no anorexia, and there was polyuria but no polydipsia. There was no history suggestive of any renal disease or of previous illness or familial disorders, and he had received no drugs or injections. On admission to hospital he was thin but showed periorbital, sacral, and leg oedema. There were no abnormalities of the cardiovascular system, and the blood pressure was $140 / 75 \mathrm{~mm}$. Hg. Scattered rhonchi were heard in the chest, and a left upper abdominal mass, possibly renal, was just palpable.
Investigations resulted as follows: haemoglobin $12 \mathrm{~g} . / 100 \mathrm{ml}$; W.B.C. $6,700 / \mathrm{cu}$. mm. ; E.S.R. $31 \mathrm{~mm}$./hour; urea $26 \mathrm{mg}$./ $100 \mathrm{ml}$.; plasma proteins $5.4 \mathrm{~g} . / 100 \mathrm{ml}$. (albumin $2.1 \mathrm{~g}$., globulin 3.3 g.) ; urine (protein) ++++ -the deposit contained a few leucocytes, red blood cells, and epithelial cells, but culture was sterile; and serum cholesterol $270 \mathrm{mg} . / 100 \mathrm{ml}$. Liver function tests, intravenous pyelogram, and chest $x$-ray and barium meal examinations were all normal. A Congo red test showed no increase in uptake. The patient improved on bed rest and was allowed home.

Three months later he was readmitted to hospital. His diarrhoea had persisted and he now had pitting oedema up to waist level. There was no anaemia or lymphadenopathy, and his blood pressure was $135 / 85$. In the abdomen there was free fluid, the liver was palpable two fingerbreadths below the costal margin, and an epigastric mass was felt. There was a recurrent evening pyrexia.

Investigations resulted as follows: E.S.R. $110 \mathrm{~mm}$./hour, haemoglobin $12 \mathrm{~g} . / 100 \mathrm{ml}$., urea $34 \mathrm{mg} . / 100 \mathrm{ml}$., serum proteins $4.4 \mathrm{~g} . /$ $100 \mathrm{ml}$. (albumin $1.5 \mathrm{~g}$., globulin $2.9 \mathrm{~g}$.), and serum cholesterol $470 \mathrm{mg} . / 100 \mathrm{ml}$. Albuminuria was pronounced $(++++)$ and the Esbach level reached $40 \mathrm{~g}$./litre. Urea clearance was $75 \%$ of normal, blood W.R. negative, alkaline phosphatase 9 K.A. units, bilirubin $0.1 \mathrm{mg} . / 100 \mathrm{ml}$, and thymol turbidity 5 units. A repeat barium-meal examination showed a large irregular filling defect in the lower part of the stomach diagnosed as carcinoma. This was confirmed at operation, when a large polypoid ulcerating tumour was found arising in the anterior gastric wall, extending $9 \mathrm{~cm}$., and infiltrating the wall; the tumour was removed by subtotal gastric resection. All other viscera were examined and found to be free of tumour, but no specific comments were made on the state of the kidneys or renal veins. Histology of the tumour was that of a moderately well differentiated adenocarcinoma, completely removed, and with spread to one local lymph node.

Following surgery the patient recovered rapidly, losing his oedema and gaining weight. Proteinuria decreased until the 19th day after operation, when no trace was detectable. At a follow-up visit 10 years later (1965) he was competely symptom-free and had no oedema or abnormal physical signs. At this time the blood urea was $28 \mathrm{mg} . / 100 \mathrm{ml}$., the serum proteins $6.9 \mathrm{~g} . / 100 \mathrm{ml}$. (albumin 5.0 g., globulin 1.9 g.) ; the urine contained no protein, there was no increase in white cells, and culture was sterile. He therefore had complete remission of both conditions. 